\title{
A construção do sentido de redenção social na carta-tes- tamento de Getúlio Vargas (1954): cristianimo, castilhismo, paganismo e outras tradições discursivas
}

\section{Alessandra Castilho da Costa ${ }^{1}$}

\begin{abstract}
From the perspective of the Discourse Traditions Model, a text may correspond to a whole series of traditions (or conventions) co-present at the same time. The main purpose of the present study consists of identifying evocation relations established between the testament-letter of Getúlio Vargas (1954) and other previous texts in history, in particular the biblical text, which contribute to the construction of the sense of social redemption in the testament-letter and to the determination of linguistic choices. By giving visibility to these intertextual and interdiscoursive relations established between the text of Vargas and other texts, the present study aims to appoint an analysis procedure with relevant theoretical, methodological and hermeneutical implications for the text and discourse studies. Since knowing the connection between text and tradition is essential to deduce the context of the text, one cannot interpret it properly unless the traditions that cross it are mapped by means of a methodology that establish distinctions between language rules and rules of discourse, actualization and evocation, tradition and innovation.
\end{abstract}

Key-words: testament-letter; discourse traditions; christianism; castilhism; paganism.

Resumo: Do ponto de vista do Modelo de Tradições Discursivas, um texto pode corresponder a toda uma série de tradições (ou convenções) co-presentes ao mesmo tempo. No presente estudo, buscamos identificar as relações de evocação que se estabelecem entre a carta-testamento de Getúlio Vargas (1954) e outros textos anteriores na História, em especial, o texto bíblico, na construção do sentido de redenção social e na determinação das escolhas linguísticas. Ao dar visibilidade a essas relações intertextuais e interdiscursivas que se estabelecem entre o texto de Vargas e outros textos, busca-se apontar um procedimento de análise, com implicações teóricas, metodológicas e hermenêuticas relevantes para os estudos do texto e do discurso. Uma vez que conhecer a ligação entre o texto e a tradição é essencial para depreender seus entornos, não se pode interpretá-lo apropriadamente a menos que as tradições que o atravessam sejam mapeadas por meio de uma metodologia que estabeleça distinções entre regras da língua e regras do discurso, atualização e evocação, tradição e inovação.

Palavras-chave: carta-testamento; tradições discursivas; cristianismo; castilhismo; paganismo.

1 Doutora em Letras (Martin-Luther-Universität Halle-Wittenberg, Alemanha), Professora Adjunta do Departamento de Letras da Universidade Federal do Rio Grande do Norte (UFRN) e do Programa de Pós-Graduação em Estudos da Linguagem (PPgEL/UFRN). Endereço eletrônico: alessandracastilho.costa@hotmail.com 
Em sua Textlinguistik (1994), Coseriu propõe a distinção de três tipos distintos de conteúdos linguísticos, a saber: a designação, o significado e o sentido. O primeiro tipo diz respeito à referência de objetos e estados de coisas; por sua vez, o significado refere-se ao que se entende por meio de uma língua ou ao conjunto do que uma língua expressa como tal (neste sentido, o português e o alemão, por exemplo, expressam significados diferentes); por fim, o sentido corresponde ao que se entende em um texto e só no texto. Com consequência, o sentido de um texto não necessariamente equivale ao que é narrado. Por isso, Coseriu argumenta que é possível a um leitor de $A$ Metamorfose de Kafka entender os eventos narrados e, ainda assim, perguntar-se qual é afinal o significado desse texto, isto é, qual é seu sentido. No contexto dessa distinção, o autor afirma que a "verdadeira" ou "legítima" linguística de texto é uma linguística do sentido.

Quais seriam, entretanto, os procedimentos de criação e compreensão do sentido? Para Coseriu, o signo linguístico funciona mediante as relações que pode estabelecer com os demais signos presentes no texto e o sentido constituiria, assim, o conjunto de todas as relações sígnicas que ali se estabelecem. Entre os variados tipos de relações sígnicas relevantes na criação e compreensão do sentido estão as tradicionalidades e convenções, que se habitualizam em diferentes níveis, tais como universos de discurso (cotidiano, religião, ciência, etc.), estilos (romantismo, sensacionalismo, maneirismo, etc.), gêneros textuais (carta pessoal, testamento, manual científico, etc.), fraseologismos ("antes tarde do que nunca"), tradições de conteúdo (o tema do amor em uma carta de amor), atos de fala tradicionais (juramento de amor e fidelidade no casamento, saudar um conhecido na rua), aspectos tradicionais relativos à estrutura composicional (a tradição do título, por exemplo), à sintaxe (o uso de parataxe em textos influenciados pela oralidade), à morfologia (uso de vós e variantes na redação oficial ou no discurso religioso), à fonologia (como a prosódia do padre na missa); em suma, qualquer tradicionalidade que se forme em relação à língua, ao conteúdo e à organização do texto. Deste ponto de vista teórico, os textos são criações (no sentido humboldtiano do novo) únicas de um indivíduo, que se realizam como atos de fala conexos com traços universais, atualizados dentro das possibilidades de uma língua histórica em uma dada situação de comunicação, independentemente de sua extensão ou meio de transmissão (gráfico ou fônico) e que evocam modos particulares de dizer, isto é, tradições discursivas que fazem parte de uma história verbal, constituindo modelos para outros atos de fala futuros.

Partindo dessas observações antecedentes, o presente estudo busca identificar tradições discursivas que desempenham um papel relevante na construção do sentido de redenção social na carta-testamento de Getúlio Vargas.

Como um dos mais importantes testemunhos históricos do messianismo político no Brasil - movimento caracterizado na literatura especializada pela expectativa de um líder político que resolverá todos os problemas da nação numa forma de libertação e redenção do povo - este documento representa um objeto de estudo relevante não somente para historiadores, mas também para linguistas, já que as questões de significação na linguagem não podem ser investigadas sem a inclusão da história. A história dos textos está relacionada à história social, já que com mudanças no campo político, econômico, cultural, religioso etc., novas necessidades comunicativas são despertadas, que, por sua vez, motivam o surgimento de novas tradições discursivas (cf. KOCH 1997, p. 57-58).

Entre os aspectos e fenômenos presentes na carta-testamento de Getúlio Vargas que foram identificados em estudos históricos e linguísticos, a partir de diferentes perspectivas teóricas, estão os seguintes: 
- emulação de Cristo por Vargas e construção de papel de mártir (OLIVEIRA 2013; VIANNA 2005);

- influência do discurso messiânico-religioso (cf. MELLO 2011; VIANNA 2005), populista (SILVA 2016), nacionalista (MELLO 2011; SILVA 2016), anti-americanista (FARES 2016), positivista e castilhista (FONSECA 2011);

- $\quad$ expressão de emocionalidade (RODRIGUES/SILVA NETO/PASSEGGI/MARQUESI 2012; SILVA 2016);

- $\quad$ estratégia retórica de elogio ao auditório (SILVA 2016);

- dupla genericidade de carta e de testamento (RODRIGUES/SILVA NETO/PASSEGGI/MARQUESI 2012);

- $\quad$ linguagem adjetivada (SILVA 2016);

- uso de $1^{\mathrm{a}}$ e $2^{\mathrm{a}}$ pessoa do plural (cf. MELLO 2011; RODRIGUES/SILVA NETO/ PASSEGGI/MARQUESI 2012; SILVA 2016);

- justaposições (RODRIGUES/SILVA NETO/PASSEGGI/MARQUESI 2012) e

- gerúndios (RODRIGUES/SILVA NETO/PASSEGGI/MARQUESI 2012).

Diante dessas considerações, as questões que guiam a presente análise são as seguintes:

i. Na construção do sentido de redenção social, quais as relações de evocação que se estabelecem entre a carta-testamento de Getúlio Vargas e outros textos anteriores na História, a exemplo da literatura bíblica? Em outras palavras, que textos podem ter influenciado a produção desse documento?

ii. A que tradições discursivas tais textos pertencem?

iii. O que a identificação de tradições discursivas revela sobre a carta-testamento de Getúlio Vargas?

iv. Como os resultados da análise contribuem para os estudos do texto e do discurso?

Essas perguntas serão consideradas a seguir em três blocos: o primeiro tratará do conceito de tradição discursiva; o segundo identificará tradições discursivas que atravessam a carta-testamento e o terceiro trará uma síntese dos resultados e suas implicações.

\section{Conceito de tradição discursiva}

Por tradição discursiva (TD), entendem-se quaisquer conteúdos, formatos textuais e formas ou formulações linguísticas que se habitualizam e se tornam tradicionais (convencionais) em virtude de sua evocação por determinadas situações ou constelações discursivas (cf. KABATEK/PUSCH 2009, p. 172). Este conceito foi desenvolvido e proposto por Peter Koch (1997) a partir dos postulados do linguista romeno Eugenio Coseriu. Em Determinación y Entorno - Dos problemas de uma linguística del hablar (1955), Coseriu define a linguagem como atividade humana universal exercida individualmente em obediência a normas de idiomas particulares históricos. Isto significa que há três níveis do linguístico: universal, histórico e individual.

Entretanto, em Diskurstraditionen: zu ihrem sprachtheoretischen Status und ihrer Dynamik (1997), Koch modifica o modelo corseriano, introduzindo uma duplicação do nível histórico: além das regras linguísticas (pertencentes às línguas particulares), o autor atribui a esse nível as tradições ou regras discursivas (KOCH 1997, p. 45). Uma distinção fundamental estabelecida pelo autor entre os dois tipos de regras reside nos 
grupos de transportadores. Enquanto regras da língua são transportadas por comunidades linguísticas (brasileiros, alemães, franceses, paulistas, cariocas, etc.) e organizam fatos puramente linguísticos, regras ou tradições discursivas são transportadas por grupos culturais (religiosos, políticos, literários, profissionais, etc.; em suma, trata-se de grupos ideológicos.). Logo, tradições discursivas não pertencem à gramática da língua, mas a objetos culturais. Neste sentido, todo enunciado é duplamente histórico, pois atualiza uma língua particular, mas também tradições discursivas.

Do ponto de vista do Modelo de TD, uma das tarefas fundamentais na análise dos textos é identificar seus aspectos tradicionais. Para tanto, a única via é a análise filológica minuciosa e detalhada com a identificação das possíveis alusões históricas de cada palavra, a abordagem da mais completa intertextualidade, isto é, um trabalho de reconstrução histórica pormenorizada (cf. KABATEK 2013, p. 13-14).

Nessa linha, a recontextualização da carta-testamento de Getúlio Vargas engloba a reconstrução dos entornos desse texto, de suas condições de produção por meio da identificação de suas relações intertextuais e interdiscursivas com outros textos que podem ter influenciado sua produção, advindos de diferentes tradições, tais como o cristianismo, o paganismo, o maquiavelismo, o helenismo, entre outros.

Aspecto importante nessa perspectiva teórica é a distinção entre intertextualidade e interdiscursividade. Koch (1997) define a intertextualidade como a alusão a um discurso individual, ao passo que a interdiscursividade se refere à ligação entre um texto e uma tradição discursiva. Logicamente, a alusão repetida a discursos individuais pode levar à formação de uma TD. Tal fato é comum nas tradições religiosas, a exemplo do cristianismo, em que a repetição das palavras de Jesus na instituição da Santa Ceia constitui uma TD que atravessa outra TD, o gênero sermão.

\section{Relações intertextuais e interdiscursivas na carta-testamento}

\subsection{Atributos divinos}

$\mathrm{Na}$ cristologia, é conhecida a doutrina das duas naturezas de Cristo, isto é, considera-se que é tão verdadeiramente divino quanto humano. Entre os atributos de divindade citados na literatura estão a onipotência, retratada nos Evangelhos por meio de milagres, a eternidade, a onisciência e a onipresença. Na emulação de Cristo que a carta-testamento constrói, o ethos de Getulio Vargas é caracterizado como detentor de natureza divina e de alguns desses atributos, tais como os atributos de eternidade e onipresença. Essa construção se dá, inicialmente em (1), por meio da evocação das palavras de Jesus ("estou convosco todos os dias"/"escolho estar sempre convosco"), mas também por meio de uma série de enumerações cujo objetivo é explicitar o modo pelo qual seu nome permanecerá na memória dos brasileiros e servirá de emblema e motivação eternos para a ação do povo $(3,4,5,6,7)$ :

1. Escolho este meio de estar sempre convosco. (carta-testamento)

2. E eis que eu estou convosco todos os dias, até a consumação dos séculos. Amém. (Mateus 28: 20)

3. Quando vos humilharem, sentireis minha alma sofrendo ao vosso lado. (cartatestamento)

4. Quando a fome bater à vossa porta, sentireis em vosso peito a energia para a luta por vós e vossos filhos. (carta-testamento) 
5. Quando vos vilipendiarem, sentireis no meu pensamento a força para a reação. (carta-testamento)

6. Meu sacrifício vos manterá unidos e meu nome será a vossa bandeira de luta. (carta-testamento)

7. Cada gota de meu sangue será uma chama imortal na vossa consciência e manterá a vibração sagrada para a resistência. (carta-testamento)

Convém fazer algumas observações sobre o uso de vós e variantes nos trechos acima. Do ponto de vista do modelo de TD, as mudanças linguísticas não se dão com a mesma velocidade em todas as TD, porque tanto o surgimento como o desaparecimento de uma forma linguística não ocorrem homogeneamente em toda a língua, mas acontecem passo a passo em gêneros textuais, até que toda a língua tenha sido afetada. Algumas formas linguísticas, como é o caso do pronome de $2^{\mathrm{a}}$ pessoa do plural vós e seus variantes podem desaparecer em determinados gêneros textuais e serem mantidas em outros. Os estudos a respeito da diacronia do quadro pronominal no Português do Brasil (PB) evidenciam que a forma "você" se inseriu no paradigma pronominal a partir do século XIX e mais intensamente no século $\mathrm{XX}$. Isto significa que a utilização de vós e variantes na carta-testamento já se configurava na segunda metade do XX como um traço arcaizante que sobrevivia apenas em TD específicas como a redação oficial e a linguagem religiosa. Nas enumerações citadas, esses itens linguísticos são, pois, sintomas de uma TD e recursos de estilização, isto é, de mímesis da linguagem religiosa arcaica, especificamente de tradição judaico-cristã.

Contudo, misturam-se a esses sintomas de TD, nesse trecho, itens linguísticos que introduzem a tradição do misticismo pagão, tais como "energia", "força", "chama imortal" e "vibração sagrada". O conceito de fogo/chama eterna/imortal, por exemplo, pode ser identificado em uma série de tradições religiosas diversas, tais como no zoroastrismo, no hinduísmo, mas também na mitologia grega, em que Prometeu, por amor aos homens, rouba algumas sementes de fogo à roda do Sol e leva-as para a Terra, escondidas num caule de férula (cf. GRIMAL 1993, p. 396).

Observa-se, portanto, em (1), (3), (4), (5), (6) e (7) o que Kabatek (2006) denomina de composicionalidade paradigmática: trata-se da concomitância de referências a diferentes tradições discursivas em uma mesma porção de texto. No trecho acima, as tradições discursivas do cristianismo e do paganismo misturam-se, servindo como filtro dos enunciados, determinando escolhas linguísticas e sofrendo elas próprias transformações (cf. KOCH 1997).

\subsection{Ofícios de Jesus e de Vargas}

É costume, na teologia cristã, falar de três ofícios com relação à obra de Jesus, a saber, os ofícios profético, sacerdotal e real. O profeta é alguém que fala da parte de Deus, que recebe uma vocação divina e uma ordem para revelar a verdade, isto é, para ser representante de Deus junto ao povo, para ser seu mensageiro e para interpretar sua vontade. Já o sacerdote fala e age em favor do povo, oferecendo dádivas e sacrifícios pelos pecados, fazendo intercessão pelo povo e abençoando-o em nome de Deus. Por fim, a realeza de Jesus é definida como o poder oficial de governar todas as coisas do céu e da terra (cf. BERKHOF 1990, p. 349-400).

$\mathrm{Na}$ evocação de textos anteriores, especialmente bíblicos, estabelece-se um paralelismo na carta-despedida e na carta-testamento entre os ofícios de Jesus e os ofícios de Getúlio Vargas. Assim, mesmo que não considere esses ofícios reflexivamente, Vargas projeta no discurso os papéis de profeta, cuja voz da verdade os inimigos desejam calar 
(8), bem como de sacerdote $(9 ; 10)$ e de rei (11). Prestes a ser entregue aos "fariseus", seus inimigos políticos (10), o Vargas-sacerdote oferece seu sangue em sacrifício e resgate pelo povo $(9,10,13,15)$ de forma análoga às palavras de Jesus quando afirma que seu sangue é vertido, seu corpo, partido e sua vida, dada em resgate por muitos (12, 14 e 16). Os trechos abaixo permitem observar tais paralelismos e evocações:

8. Precisam sufocar minha voz e impedir minha ação para que eu não continue a defender, como sempre defendi, o povo e principalmente os humildes. (carta-testamento)

9. Nada mais vos posso dar a não ser o meu sangue. (carta-testamento)

10. Que o sangue dum inocente sirva para aplacar a ira dos fariseus. (carta-despedida)

11. Depois de decênios de domínio e espoliação dos grupos econômicos e financeiros internacionais, fiz-me chefe de uma revolução e venci. (carta testamento)

12. E, tendo dado graças, o partiu e disse: Tomai, comei; isto é o meu corpo que é partido por vós; fazei isto em memória de mim. Semelhantemente também, depois de cear, tomou o cálice, dizendo: Este cálice é o novo testamento no meu sangue; fazei isto, todas as vezes que beberdes, em memória de mim. 1 Coríntios 11: 24-25

13. Meu sacrifício ficará para sempre em sua alma e meu sangue terá o preço do seu resgate. (carta-testamento)

14. Porque o Filho do homem também não veio para ser servido, mas para servir e dar a sua vida em resgate de muitos. Marcos 10: 45

15. Eu vos dei a minha vida. (carta-testamento)

16. Assim como o Pai me conhece a mim, também eu conheço o Pai, e dou a minha vida pelas ovelhas. João 10: 15

Por meio da construção das imagens que o enunciador projeta no discurso, são evocados diferentes tipos de conhecimento partilhados pelos membros de uma determinada sociedade. Neste contexto, Assmann (1988, 1992: 50) distingue entre memória comunicativa e memória cultural. O primeiro tipo de conhecimento diz respeito ao passado recente, à comunicação cotidiana e às lembranças partilhadas por indivíduos contemporâneos. Já a memória cultural corresponde ao conhecimento do passado longínquo e das figuras simbólicas a ele relacionadas. Esta distinção parece ser elucidativa com relação aos trechos citados acima.

Na construção do sentido do enunciado "Que o sangue dum inocente sirva para aplacar a ira dos fariseus", é necessário que na memória do co-enunciador estejam presentes o papel de Pilatos no julgamento de Cristo, seu veredito de que Jesus era inocente, sua decisão de entregá-lo, seu ato simbólico de lavar as mãos, entre outros elementos. Neste trecho da carta-despedida, a estratégia utilizada pelo enunciador é, portanto, a evocação de conhecimentos partilhados na memória cultural. A evocação desses conteúdos por Vargas ocorre também em discursos anteriores, a exemplo do discurso pronunciado em 13 de maio de 1938 no Palácio do Catete em agradecimento à manifestação popular de repúdio ao levante integralista de 11 de maio (D’ARAUJO 2011, p. 375):

17. Na madrugada de 11 de maio, os inimigos da pátria erigiram a violência e o ódio faccioso em norma de ação. Os indivíduos que assaltaram casas residenciais para trucidar os seus moradores eram, na generalidade, meros sicários sem qualificação social, sem profissão conhecida. Os chefes e seus prepostos imediatos fugiram acovardados; os mandantes e instigadores negam as responsabilidades e lavam, na bacia de Pilatos, as mãos tintas do sangue que fizeram derramar. 
Embora os ofícios de sacerdote e rei recebam maior ênfase que o de profeta na cartatestamento, pode-se supor que na memória de seus leitores estava ainda bem presente a aura de misticismo construída em torno do enunciador, em vista da projeção consciente da imagem de Vargas como profeta e homem providencial, em particular, no discurso jornalístico. Aqui se trata da memória comunicativa, isto é, das lembranças partilhadas por sujeitos contemporâneos que podem ser investigadas a partir dos gêneros textuais pertencentes a essa esfera. Pistas dessas imagens projetadas no discurso podem ser encontradas, por exemplo, em alguns editoriais publicados no jornal $O$ Imparcial, pertencentes à pena do jornalista e ghost writer José Soares Maciel Filho, em que tais imagens são mais nitidamente delineadas: nesses trechos, Vargas é o profeta, o homem providencial, que prevê o futuro com precisão, que continua vendo o dia de amanhã, que fala com serenidade, que tem inspiração providencial e cujas palavras são o espírito da Nação:

18. Errare humanum est. E não se admite um erro em quem teve previsão divina. $\mathrm{O}$ profeta, porém, ainda não cerrou os olhos e continua vendo o dia de amanhã. (José Soares Maciel Filho, O Homem Providencial: acção invisível e inacção coordenadora, jornal O Imparcial, 8/12/1937)

19. Getulio Vargas sente a emoção do povo brasileiro e sabe que suas palavras são o espirito da Nação. (José Soares Maciel Filho, $O$ alto sentido de um discurso, jornal O Imparcial, 02/12/1940)

20. Getulio Vargas disse hontem o sentimento nacional. Não pronunciou suas palavras como afirmação demagógica para impelir multidões ou conquistal-as com a musica do heroísmo. Falou com a serenidade consciente de um profeta, de um homem que além das sombras do dia de hoje descortina com precisão o futuro [...] (José Soares Maciel Filho, $O$ alto sentido de um discurso, jornal O Imparcial, $02 / 12 / 1940)$

21. Getulio Vargas falou em nome do povo brasileiro e mostrou ao mundo a posição onde nos encontramos preparados para a defesa dos nossos ideais e das nossas tradições. Estamos mobilizando todas as nossas forças morais e materiais em defesa do continente. A inspiração providencial de 10 de Novembro nos permitiu uma preparação antecipada no campo das forças morais. (José Soares Maciel Filho, Inspiração providencial, jornal O Imparcial, 11/11/1941)

Não parece ser coincidência que a carta-testamento seja concluída com uma alusão a essa mesma serenidade de profeta ("Serenamente dou o primeiro passo no caminho da eternidade e saio da vida para entrar na história"). Ainda nos trechos acima, o conceito de "homem providencial" evoca as ideias de Maquiavel e designa aqueles homens que a Sorte ou Fortuna usa para impor sua vontade ("Certamente é o curso da Fortuna, quando ela deseja conseguir algum grande resultado, selecionar para seu instrumento um homem dotado de espírito e habilidade, capaz de reconhecer a oportunidade que lhe é oferecida", MAQUIAVEL, Discursos, II, 29, apud LEDEEN 1999, p. 59)

Tanto este último conceito quanto o de "destino" que ocorre na carta-testamento ("Sigo o destino que me é imposto") inscrevem-se em uma cosmovisão pagã, na qual a Fortuna é concebida como uma deusa, responsável por parte do governo das ações humanas ("A fortuna, como mulher, é sempre amiga dos jovens [...]”; “[...] acredito poder ser verdadeiro o fato de que a fortuna arbitre metade das nossas ações, mas que, mesmo assim, ela nos permita governar a outra metade quase inteira, MAQUIAVEL 1999, p. 146 e 143)". Tal perspectiva contrapõe-se à cosmovisão cristã, em que é Deus que governa o mundo e não o acaso ou outra deidade. 
Além dessa mistura de imagens advindas de tradições discursivas distintas, observa-se na carta-testamento a evocação de enunciados que remetem também à figura de apóstolo, mais especificamente de Paulo, que não somente buscava imitar a Cristo, como também assim ensinava aos cristãos ("Sede meus imitadores, como também eu sou de Cristo", 1 Coríntios 11:1). Deste modo, em sua emulação de Cristo, Vargas também emula Paulo, mesclando às imagens de profeta, sacerdote e rei, também a imagem de apóstolo-imitador de Cristo. Assim, enquanto Paulo afirmava que morria a cada dia no trabalho do evangelho, Vargas defende, na carta-testamento, que lutava mês a mês, dia a dia, hora a hora pelo povo $(22 ; 23)$; enquanto Paulo tudo suportava e sofria pelos escolhidos, Vargas tudo suportava em silêncio (22, 24 e 25); enquanto Cristo esvaziou-se a si mesmo, Vargas renunciou a si mesmo (26 e 27$)$ :

22. Tenho lutado mês a mês, dia a dia, hora a hora, resistindo a uma pressão constante, incessante, tudo suportando em silêncio, (carta-testamento)

23. Eu protesto que cada dia morro, gloriando-me em vós, irmãos, por Cristo Jesus nosso Senhor. 1 Coríntios 15:31

24. [...] antes suportamos tudo, para não pormos impedimento algum ao evangelho de Cristo. 1 Coríntios 9: 12

25. Portanto, tudo sofro por amor dos escolhidos, para que também eles alcancem a salvação que está em Cristo Jesus com glória eterna. 2 Timóteo 2: 10

26. tudo esquecendo e renunciando a mim mesmo, para defender o povo que agora se queda desamparado (carta-testamento)]

27. Mas esvaziou-se a si mesmo, tomando a forma de servo, fazendo-se semelhante aos homens; Filipenses 2: 7

No discurso de Vargas, as imagens de Cristo como profeta, sacerdote e rei advindas da tradição discursiva do cristianismo não se repetem da mesma maneira, antes servem a uma nova e particular combinação com outras imagens, a exemplo do homem providencial, advindas de tradições como o estoicismo e o maquiavelismo. Na carta-testamento, a convergência e mistura dessas TD perseguem o objetivo de fixar uma interpretação dos acontecimentos e articulá-los não como de fato foram, mas a partir do imaginário messiânico, em que a história do governo Vargas é transmudada com o sentido de redenção, porém, de uma redenção social, por meio de um sistema de liberdade social, que apelava a um público amplo composto de grupos culturais diversos, tais como religiosos cristãos, religiosos espíritas, trabalhadores, nacionalistas, entre outros.

Em consequência, contrapõem-se o testamento de Vargas e o testamento de Jesus também com relação aos seus respectivos ensinos. Três são os aspectos a serem comparados, na sequência, a partir da carta-testamento e da carta-despedida: a) a temática da pobreza; b) o conceito de liberdade e c) as forças que se opõem como inimigos.

\subsection{O ensino a respeito da pobreza e da liberdade}

Com respeito à temática da pobreza, Jesus ensinou que o uso de recursos materiais é um meio de expressão de amor e um índice da relação do indivíduo com Deus, pois ao alimentar os famintos, é ao próprio Deus Filho que a pessoa serve (28). Trata-se aqui de uma visão espiritual das coisas terrenas. Já na carta-testamento, a pobreza é abordada no âmbito da luta por justiça social e da luta de classes. De um lado, estão as castas privilegiadas (30), os poderosos $(30 ; 31)$, aqueles que se opõem aos interesses nacionais (31); de outro, o povo brasileiro $(29 ; 32 ; 33)$, os necessitados $(29)$, os pobres $(31)$ e os humildes $(31 ; 32)$. 
28. [...] porque tive fome, e me destes de comer; tive sede, e me destes de beber; era forasteiro, e me hospedastes; estava nu, e me vestistes; enfermo, e me visitastes; preso, e fostes ver-me. Mateus 25: 34-36

29. Levo o pesar de não ter podido fazer, por este bom e generoso povo brasileiro e principalmente pelos mais necessitados, todo o bem que pretendia. (cartadespedida)

30. Tornei-me perigoso aos poderosos do dia e às castas privilegiadas. (carta-despedida)

31. Velho e cansado, preferi ir prestar contas ao Senhor, não dos crimes que não cometi, mas de poderosos interesses que contrariei, ora porque se opunham aos próprios interesses nacionais, ora porque exploravam, impiedosamente, aos pobres e aos humildes. (carta-despedida)

32. Precisam sufocar a minha voz e impedir a minha ação, para que eu não continue a defender, como sempre defendi, o povo e principalmente os humildes. (carta-testamento)

33. Lutei contra a espoliação do Brasil. Lutei contra a espoliação do povo. (carta testamento)

Neste contexto, Viana (2005) descreve o sentido que o conceito de liberdade adquire na carta-testamento como de liberdade social através dos direitos trabalhistas e de abolição da subordinação em relação aos interesses dos conglomerados econômicos e financeiros internacionais. Quer dizer, este conceito de liberdade está ligado à igualdade de direitos de pobres, ricos, patrões e empregados na perspectiva do trabalhismo. Liberdade é, portanto, dessa perspectiva, liberdade social, no sentido de igualdade dos direitos de todos, de equilíbrio entre classes e de garantia de direitos para os operários. Na carta-testamento, esse sentido de liberdade como seguridade de direitos trabalhistas e de nacionalização dos recursos ocorre de certa forma apenas implicitamente em (34), mas progride tematicamente mediante menções à liberdade social, à liberdade nacional, à espoliação dos grupos econômicos e financeiros internacionais, aos lucros das empresas estrangeiras, aos ódios contra a justiça da revisão do salário mínimo, etc. Vargas defende que seu sacrifício assegurará a continuação dessa obra de libertação, já que estará presente na consciência de todos eternamente, motivando-os a lutar pelos direitos trabalhistas e nacionais. Disto resultaria que o povo não seria mais escravo de ninguém (36). Neste mesmo trecho, a antítese "era escravo"/"me liberto" evoca outra antítese, aquela utilizada pelo apóstolo Paulo em 1 Coríntios 9: 19 ("sendo livre"/"fiz-me servo").

De um lado, em sua teologia, Paulo estava livre das leis cerimoniais e da maldição da lei moral, usufruindo da "lei de liberdade" em Cristo (Gálatas 5: 1), livre de qualquer necessidade de mérito próprio e de ter de obedecer a tradições de homens. De outro, estava preso ao serviço de Deus por gratidão e, assim, menciona que, "sendo livre para com todos, fiz-me servo de todos", quer dizer, suportando aflições, comportando-se com humildade e adaptando-se a todos para pregar o evangelho e colaborar na libertação dos outros da maldição da lei e do pecado.

As antíteses formuladas por Paulo e Vargas são simetricamente inversas: por uma parte, Paulo era livre e se faz voluntariamente servo; por outra, Vargas era escravo do povo e se faz livre. Assim, na carta-testamento, Vargas surge como um duplo do apóstolo, como imagem no espelho: ambos sofredores pelo povo, ambos renunciando aos próprios interesses em virtude dos interesses de outrem; ambos movidos pelo objetivo de libertar; 
contudo, na imagem projetada, à liberdade espiritual do pecado por meio do sacrifício de Jesus a que o apóstolo alude (37) contrapõe-se a liberdade social por meio dos direitos trabalhistas que Vargas apregoa e pela qual se sacrifica (36).

34. Iniciei o trabalho de libertação e instaurei o regime de liberdade social.

35. Quis criar a liberdade nacional na potencialização das nossas riquezas através da Petrobras, mal começa esta a funcionar a onda de agitação se avoluma.

36. Era escravo do povo e hoje me liberto para a vida eterna. Mas esse povo, de quem fui escravo, não mais será escravo de ninguém. (carta-testamento)

37. Porque, sendo livre para com todos, fiz-me servo de todos para ganhar ainda mais. 1 Coríntios 9: 19

\subsection{As forças oponentes}

Com relação aos objetos do discurso que a carta-despedida e a carta-testamento desenvolvem como forças que se opõem a Vargas, os inimigos (38) são malignos, rancorosos (39), hipócritas, traidores, sicários (40), poderosos, privilegiados (41), fariseus (42); são as forças e os interesses contra o povo (43), os grupos internacionais e nacionais que fazem campanhas subterrâneas (44) e aves de rapina (45). Entre a carta-despedida e a carta-testamento, faz-se notar uma mudança de perspectiva: na carta-despedida, a função emotiva da linguagem (cf. JAKOBSON 1960) revela-se por meio de expressões avaliativas, pejorativas e insultos que têm por objetivo a manifestação e o alívio do estado psíquico do enunciador. Nesta direção, alguns estudos a respeito da carta-despedida mencionam um Vargas "amargurado".

Embora claros aspectos emocionais estejam presentes na carta-testamento, tais expressões dão lugar a objetos do discurso mais impessoais, institucionais e incorpóreos, como "as forças e os interesses contra o povo" e "os grupos internacionais e nacionais". Como bem observado por Vianna (cf. 2005), os interesses dos conglomerados econômicos e financeiros internacionais são tratados na carta-testamento como forças misteriosas do mal, forças subterrâneas. O adjetivo "subterrânea" evoca aspectos relativos à descrição do inferno inscritos no imaginário judaico-cristão, tal como a noção de que o inferno se localizaria em algum lugar ou dimensão inferior à terra. Em Mateus 11: 23, por exemplo, Jesus diz: “Tu, Cafarnaum, elevar-te-ás, porventura, até o céu? Descerás até o inferno [...]". Na literatura hermenêutica, porém, a expressão "descer até o inferno" não é entendida como uma referência literal a uma direção física, mas metafórica ao evento de ser condenada. Corroborando essa interpretação, estudos na área de Linguística Cognitiva postulam que uma das metáforas recorrentes entre as línguas consiste no esquema de imagem para cima/para baixo que permite a descrição metafórica de situações do mundo real, tais como minha moral subiu ou ele conheceu altos lugares (cf. Cançado 2005, p. 100). Portanto, a expressão "subterrânea" evoca a noção de inferno do imaginário judaico-cristão e alude às forças oponentes a Vargas como demoníacas ou infernais (48).

Além dessa mudança de perspectiva entre uma carta e outra, cabe notar uma semelhança: os termos "fariseus" (46), na carta-despedida, e "aves de rapina", na carta-testamento, evocam passagens do Novo Testamento em que Jesus interage com seus oponentes, em especial, com os fariseus, grupo político-religioso interno ao judaísmo que advogava um rígido código de conduta. Em Mateus 23: 25, Jesus faz referência à hipocrisia da observância desse código de tradições ao mencionar as regras de limpeza que os fariseus 
seguiam com respeito aos copos e pratos. A passagem opõe, nas palavras de Jesus, a limpeza exterior (isto é, a aparência de pureza) dos fariseus e sua imundície interna, revelada na opressão de pobres, viúvas e órfãos, extorquidos e usados pelos fariseus (ou, nas palavras de Vargas, "aves de rapina") em favor de sua intemperança e desejo de suntuosidade (46). Na teologia crista, o anti-cristo é entendido como o adversário de Cristo, alguém que se opõe por meio de obras e palavras. Para a presente contraposição, a passagem de Mateus é relevante por trazer a imagem de um desses anticristos, dos fariseus, poderosos e privilegiados, hipócritas e gananciosos retratados no Novo Testamento, que é evocada na carta-testamento a fim de reforçar a malignidade dos oponentes de Vargas e, ao mesmo tempo, corroborar seu papel de Messias. Se Jesus se tornou perigoso aos fariseus, Getúlio Vargas afirma ter se tornado perigoso aos poderosos (41).

38. Deixo à sanha dos meus inimigos, o legado da minha morte. (carta-despedida)

39. A mentira, a calúnia, as mais torpes invencionices foram geradas pela malignidade de rancorosos e gratuitos inimigos numa publicidade dirigida, sistemática e escandalosa. (carta-despedida)

40. [...] a felonia de hipócritas e traidores a quem beneficiei com honras e mercês, à insensibilidade moral de sicários que entreguei à Justiça, (carta-despedida)

41. Tornei-me perigoso aos poderosos do dia e às castas privilegiadas. (carta-despedida)

42. Que o sangue dum inocente sirva para aplacar a ira dos fariseus. (carta-despedida)

43. "Mais uma vez as forças e os interesses contra o povo coordenaram-se e se desencadeiam sobre mim. (carta-testamento)

44. A campanha subterrânea dos grupos internacionais aliou-se à dos grupos nacionais revoltados contra o regime de garantia do trabalho. (carta-testamento)

45. Se as aves de rapina querem o sangue de alguém, querem continuar sugando o povo brasileiro, eu ofereço em holocausto a minha vida. (carta-testamento)

46. Ai de vós, escribas e fariseus, hipócritas! pois que limpais o exterior do copo e do prato, mas o interior está cheio de rapina e de intemperança. Mateus 23: 25

Uma possível explicação para a mudança de perspectiva entre as duas cartas na expressão da temática das forças que se opõem pode residir na mudança de autoria, já que, nos escritos de José Soares Maciel Filho publicados no jornal $O$ Imparcial, muitas são as evidências da influência do imaginário religioso judaico-cristão na abordagem de temas políticos, em especial, nas menções a Getúlio Vargas. Se a carta-testamento é de lavra de Getúlio Vargas ou de José Soares Maciel Filho é um tema interessante nesse contexto. Entretanto, esta é uma pergunta que não pode ser investigada no âmbito do presente estudo.

\subsection{Redenção, cristianismo e castilhismo}

Na Antiguidade Clássica, a ideia de sofrimento substitutivo era uma característica familiar: um herói podia morrer pela sua cidade, pelos seus amigos, ou mesmo por causa da verdade filosófica, sendo essa morte entendida como um sacrifício de expiação, mediante o qual a ira dos deuses era aplacada (cf. LETHAM 2007, p. 133). A substituição penal, como categoria conhecida do mundo antigo pagão, é uma tradição discursiva que atravessa uma série de textos e personagens da cultura helenística: assim, Meneceu sacrifica-se 
por Tebas; Ifigênia propõe-se a morrer para apaziguar a ira de Ártemis; Sócrates entregase à morte por suas ideias filosóficas; também Protogenia e Pandora, Ísqueno, Macária, entre muitos outros, poderiam ser citados. Portanto, o morrer pela pátria e/ou pelo povo é um topos tradicional que se estende desde a Antiguidade até o presente, especialmente na retórica política e religiosa.

Também no judaísmo, este não era um conceito desconhecido. No Antigo Testamento, encontramos demais exemplos de sacrifício voluntário nas histórias de Sansão, Isaque e Daniel. Na terminologia bíblica, "redimir", "resgatar", "redenção" e "resgate" contêm a ideia de libertação por meio do pagamento de um resgate ou pela compra no mercado. Na perspectiva do cristianismo, no Novo Testamento, esse resgate ou preço foi a vida de Jesus (cf. HENGEL 1981, apud LETHAM 2007, p. 146).

Essas observações permitem concluir que a noção de redenção muito provavelmente constitui um conteúdo da experiência humana universal, não estando restrita apenas à religião, nem especificamente ao cristianismo; antes, trata-se de um signo também no discurso político, como a expressão "morrer pela pátria” tão bem sumariza.

Se a redenção, quanto ao seu status semiótico, pode ser um signo universal, poderse-ia perguntar por que Vargas utiliza elementos específicos da TD do cristianismo na construção de paralelismos com seu papel como líder da nação. Por que estabelecer um paralelismo com essa tradição, com esse sistema semiótico especificamente?

Tal pergunta não pode ser respondida de uma maneira completa no âmbito deste artigo nem se pretende aqui fornecer uma explicação última e definitiva. Contudo, uma possível resposta poderia estar relacionada a conteúdos específicos que se habitualizaram nos textos de dois grupos culturais distintos, como o cristianismo e o castilhismo, e às interações entre os dois grupos culturais no Estado Novo.

Por uma parte, o sacrifício de expiação de Jesus distingue-se de outros com relação a pelo menos dois aspectos (cf. LETHAM 2007, p. 133): a) Jesus não morreu como herói, mas como um criminoso, condenado injustamente; b) também não morreu por uma razão limitada e específica, mas por toda a culpa humana. Esses dois aspectos fazem da morte de Cristo o sacrifício expiatório por excelência.

Por outra, a opção pela apropriação das imagens de Cristo parece estar relacionada à adesão de Vargas ao castilhismo. Segundo Rodríguez (cf. 2010, p. 19), o castilhismo constitui a corrente de pensamento com influência positivista, baseada nas ideias de Júlio de Castilhos (1840-1923). A filosofia política positivista pressupõe que a sociedade caminha inexoravelmente rumo à estruturação racional por meio do cultivo da ciência social. No castilhismo, em particular, a educação dos espíritos para que o regime positivo se instaure como fruto de um esclarecimento deve ser imposta pela organização positiva da sociedade por parte da maioria esclarecida. Por isso, a moralidade deve ser a nota primordial do governante e é caracterizada, pela tradição castilhista, como "imaculada pureza de intenções" (cf. p. 21).

Tendo em vista os requisitos de "imaculada pureza de intenções", de moralidade como nota primordial, parece natural que Vargas escolhesse construir uma imagem semelhante à de Jesus, não somente em função do exemplo de sacrifício voluntário, mas também em virtude de seus ensinamentos morais, dentre os quais estão a conhecida regra de ouro mencionada no Sermão do Monte. O caráter missionário e sacerdotal dos líderes da nação em seu propósito de redenção social, mencionado por Rodríguez acima, motivam, pois, a utilização de tradições discursivas do universo religioso.

Além desses aspectos teológicos e filosóficos convergentes, há, ainda, as motivações eleitorais, políticas e históricas que levam a um alinhamento entre catolicismo e castilhis- 
mo, entre Igreja e Estado Novo, de maneira que a partir do alinhamento político desses dois grupos culturais distintos resulta um alinhamento ou convergência de suas respectivas tradições discursivas:

O camaleônico político, ao lado de outros tantos papéis que representou, assumiu a perso$n a$, senão do católico devoto, que realmente jamais pretendeu ser, a de benfeitor da religião da maioria dos brasileiros. Verdadeiramente, no ocaso de sua trajetória, o grande líder deixa entrever a feição problemática de sua relação com o catolicismo. As duas forças apoiaram-se mutuamente, engrandecendo-se no processo. A trajetória política de Getúlio desligada da religião é incompreensível. [...]A busca da legitimação, por parte de Vargas, o lançou nos braços da instituição que foi por década ignorada pela sociedade política. (Mendonça/ Pereira/Rodrigues/Loss 2011, p. 284)

Assim, a partir da evocação de tradições discursivas bíblicas e pagãs, produz-se, na carta-testamento, um sistema de crenças e de símbolos que tem por fim sacralizar a política ou, dito noutra forma, transformá-la numa forma de religião e de culto de um ser que, neste caso, é o próprio enunciador, Getúlio Vargas. Por isso, a carta-testamento é tanto um meio de deificação de Vargas como Messias-Redentor dos socialmente oprimidos por meio de seu sacrifício voluntário quanto de estímulo à devoção. É a esperança de que sua carta resultará em fervor religioso em torno de seu nome (semelhantemente ao que ocorreu com Jesus) que lhe leva a afirmar que saía "da vida para entrar na História".

Nas considerações de Lira Neto a respeito da figura histórica de Vargas e sua obra (2014, p. 351), fica clara essa dimensão não apenas política, mas também religiosa do plano de redenção social de Vargas:

Amado e odiado com simultânea veemência, venerado e satanizado com idêntico ardor, Getúlio segue a dividir opiniões, provocar contendas, gerar reações passionais. Por certo, o melhor caminho para compreendê-lo, em perspectiva histórica, não é o da devoção sincera ou o da negação irrestrita. Em algum ponto equidistante entre uma e outra margem, entre a adoração e o repúdio, deve estar a melhor maneira de se perceber e decifrar o mito.

Quanto a essa compreensão histórica de Getúlio Vargas, o presente estudo espera ter contribuído nessa direção por meio da identificação de tradições discursivas copresentes na carta-testamento, que muito revelam de suas crenças e intenções.

\subsection{Quadro Sinóptico}

\begin{tabular}{|l|l|}
\hline \multicolumn{2}{|c|}{ Quadro sinóptico da contraposição } \\
\hline \multicolumn{1}{|c|}{ Jesus Cristo } & \multicolumn{1}{|c|}{ Cristo emulado de Getúlio Vargas } \\
\hline $\begin{array}{l}\text { Atributos de eternidade, onisciência, oni- } \\
\text { potência e onipresença }\end{array}$ & Atributos de eternidade e onipresença \\
\hline $\begin{array}{l}\text { Ofícios de profeta, sacerdote e rei (esco- } \\
\text { lhido de Deus); possuía apóstolos, dentre } \\
\text { eles, Paulo }\end{array}$ & $\begin{array}{l}\text { Ofícios de profeta, sacerdote, rei e } \\
\text { apóstolo-imitador de Cristo (escolhido de } \\
\text { Deus); homem providencial (escolhido da } \\
\text { Fortuna) }\end{array}$ \\
\hline
\end{tabular}




\begin{tabular}{|l|l|}
\hline $\begin{array}{l}\text { Ensinou a caridade aos pobres como ex- } \\
\text { pressão de amor a Deus (relação espiri- } \\
\text { tual) }\end{array}$ & $\begin{array}{l}\text { Protegia os humildes da exploração pelas } \\
\text { classes privilegiadas (luta de classes) }\end{array}$ \\
\hline $\begin{array}{l}\text { Liberdade espiritual do pecado por meio } \\
\text { do seu sacrifício }\end{array}$ & $\begin{array}{l}\text { Liberdade social da exploração por meio } \\
\text { de direitos trabalhistas e do sacrifício de } \\
\text { Vargas }\end{array}$ \\
\hline $\begin{array}{l}\text { Anticristo e anticristos: forças humanas e e } \\
\text { demoníacas que se opõem a Deus }\end{array}$ & Anticristo: ricos e interesses estrangeiros \\
\hline Redenção espiritual & Redenção social e moral \\
\hline
\end{tabular}

\section{Considerações Finais}

No presente estudo, a identificação de tradições discursivas na carta-testamento de Getúlio Vargas foi o ponto de partida para a reflexão sobre a construção do sentido de redenção social no texto em questão e para a discussão das implicações que o conceito de tradição discursiva traz para os estudos do texto e do discurso.

Em síntese, apresentamos aqui os principais resultados da análise desenvolvida com respeito (a) à identificação de TD; (b) à investigação da carta-testamento como texto e (c) à contribuição do conceito de TD para os estudos do texto e do discurso:

I. A carta-testamento é atravessada por uma série de tradições discursivas, tanto da esfera religiosa quanto política. Entre as principais influências observadas estão o cristianismo, o paganismo e o castilhismo (vide quadro 1, abaixo). Comprova-se, assim, a hipótese de Kabatek (2012) relativa à copresença de diversas tradições em um mesmo texto.

II. A intenção que se reconhece na carta-testamento é fazer com que seu leitor/ouvinte creia que Getúlio Vargas havia se sacrificado pela redenção social do povo brasileiro, isto é, pela defesa de direitos trabalhistas e interesses nacionalistas, e, com isso, provocar por parte dos co-enunciadores uma forma de culto e devoção religiosa ao enunciador. Nessa direção, a carta-testamento constrói, a partir de signos advindos de tradições discursivas diversas, um novo sistema de símbolos para a deificação de Getúlio Vargas. Entre as tradições mais relevantes para esse propósito está o topos da redenção, habitualizado em diferentes discursos, tanto religiosos ("morrer pelos pecadores") quanto políticos ("morrer pela pátria").

III. Entre as estratégias de deificação de Vargas, destaca-se a emulação de Cristo com respeito a diferentes aspectos, tais como atributos divinos, como os de onipresença e eternidade, seus ofícios de profeta, sacerdote e rei e seus ensinamentos a respeito da pobreza e da liberdade. Além da emulação de Jesus, identificamos a emulação do apóstolo Paulo por meio da evocação de suas palavras, bem como mais indiretamente a projeção de homem providencial (escolhido da Fortuna ou do Destino). De um lado, as evocações relativas às palavras de Jesus e de Paulo são mais explícitas, de modo que as semelhanças de formulação puderam ser apontadas. Por outro, a imagem de profeta e de homem providencial aparece de forma mais implícita no texto, embora possa ter sido bastante presente na memória comunicativa da sociedade naquele momento. Aqui se mostraram rele- 
vantes as relações da carta-testamento com os evangelhos, as epístolas paulinas e alguns editoriais escritos por José Soares Maciel Filho e publicados no jornal O Imparcial.

IV. O uso de vós e variantes na carta-testamento na segunda metade do XX constituía um traço arcaizante da língua em função das mudanças do quadro pronominal do PB a partir do século XIX. Como forma linguística em desaparecimento das regras da língua, vós e seus variantes sobreviviam já nessa época em TD específicas como a redação oficial e a linguagem religiosa. Esse aspecto microestrutural é motivado textualmente, quer dizer, trata-se de um sintoma de TD que serve à mímesis da linguagem religiosa arcaica, especificamente de tradição judaico-cristã.

V. Determinadas evocações, a exemplo do papel de Pilatos no julgamento de Cristo ou dos fariseus, ocorrem não somente na carta-testamento como também na carta-depedida e em um discurso pronunciado por Vargas em 13 de maio de 1938 no Palácio do Catete. Isso parece evidenciar que a utilização de signos da tradição discursiva do cristianismo era um traço não restrito à carta-testamento, mas presente, de modo mais amplo, em outros textos produzidos (ou pelo menos pronunciados e/ou assinados) por Vargas.

VI. Impõe-se, nesse contexto, o problema da autoria da carta-testamento. É certo que tanto os discursos pronunciados por Vargas quanto a carta-testamento não necessariamente partiram de sua própria pena. Essa é, aliás, uma hipótese que tem sido aventada por diversos historiadores. Constatamos, em nossa análise, a mudança de perspectiva na representação das forças oponentes que ocorre da carta-despedida para a carta-testamento. Também constatamos que a influência do imaginário religioso judaico-cristão na abordagem de temas políticos, em especial, nas menções a Getúlio Vargas, é um traço dos escritos de Maciel Filho. Em vista dessas duas constatações, uma hipótese a ser investigada ulteriormente é a existência de similaridades entre as formulações de cunho religioso e cristológico presentes na carta-testamento e nos pronunciamentos de Vargas, de um lado, e as produções assinadas pelo jornalista, de outro.

Em diferentes partes da carta-testamento, identificou-se a mistura de TD, como, por exemplo, a fusão das imagens de Cristo como profeta, sacerdote e rei, advindas da tradição discursiva do cristianismo, com a de homem providencial, advinda do maquiavelismo. Este processo de inovação por fusão de TD comprova a composicionalidade paradigmática das TD, isto é, a confluência de referências a diferentes TD em um mesmo fragmento de texto. Daí resulta a conclusão de que os elementos que formam uma tradição apresentam-se frequentemente em combinação com outros elementos, e precisamente a combinação de vários elementos pode formar uma tradição discursiva. Segundo Kabatek (2005, p. 161), as possibilidades de transformação de uma TD derivam justamente de seu caráter composicional. Além da confluência de TD distintas em um mesmo fragmento de texto, os resultados da análise apontam para a sucessão de elementos de diferentes TD ao longo do texto (composicionalidade sintagmática), como o quadro abaixo ilustra. Para os estudos do texto e do discurso, tais resultados são relevantes, tendo em vista que é o caráter composicional das TD que permite sua inovação e a criação de novas TD. 


\begin{tabular}{|c|c|c|c|c|}
\hline \multicolumn{4}{|c|}{ Tradições Discursivas evocadas } & Carta-testamento \\
\hline & \multicolumn{3}{|c|}{$\begin{array}{l}\text { Carta-despedida }->\text { "malignidade de rancorosos e gratuitos ini- } \\
\text { migos"; "ira dos fariseus" } \\
\text { Cristianismo -> forcas do mal; anticristo }\end{array}$} & $\begin{array}{l}\text { "[...] as forças e os interesses contra o povo coordena- } \\
\text { ram-se e se desencadeiam sobre mim"; "a campanha } \\
\text { subterrânea dos grupos internacionais [...]" }\end{array}$ \\
\hline & \multicolumn{3}{|c|}{$\begin{array}{l}\text { Carta-despedida -> "Levo o pesar de não ter podido fazer, por } \\
\text { este bom e generoso povo brasileiro e principalmente pelos mais } \\
\text { necessitados, todo o bem que pretendia". } \\
\text { Cristianismo -> ideal de caridade aos pobres } \\
\text { Trabalhismo -> ideal de justiça social e luta de classes } \\
\text { Castilhismo -> ideal de imaculada pureza de intenções }\end{array}$} & "Sempre defendi o povo e principalmente os humildes" \\
\hline & Paganismo -> & Maquiavelismo > & $\begin{array}{l}\text { Editoriais } 0 \text { Imparcial }> \\
\text { Homem providencial }\end{array}$ & "Sigo o destino que me e imposto" \\
\hline & \multicolumn{3}{|c|}{$\begin{array}{l}\text { Trabalhismo-> conceito de liberdade social por meio de direitos } \\
\text { trabalhistas }\end{array}$} & "Iniciei o trabalho de libertação" \\
\hline & \multicolumn{3}{|c|}{ Cristianismo $->$ palavras de Paulo $->1$ Coríntios 15:31 } & "Tenho lutado mês a mês" \\
\hline & \multicolumn{3}{|c|}{$\begin{array}{l}\text { Cristianismo -> palavras de Paulo -> } 1 \text { Coríntios 9: 12; } 1 \text { Co- } \\
\text { ríntios } 13\end{array}$} & "tudo suportando em silencio" \\
\hline & \multicolumn{3}{|c|}{ Cristianismo $->$ palavras de Jesus $->$ Filipenses $2: 7$} & "tudo esquecendo e renunciando a mim mesmo" \\
\hline 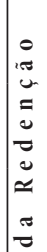 & \multicolumn{3}{|c|}{$\begin{array}{l}\text { Carta-despedida }->\text { "Que o sangue dum inocente sirva para } \\
\text { aplacar a ira dos fariseus". } \\
\text { Cristianismo -> Pilatos "Estou inocente do sangue deste justo" } \\
\text { Mateus 27: } 24 \\
\text { Discurso de Vargas pronunciado em 13/05/1938 - "lavam, na } \\
\text { bacia de Pilatos, as mãos tintas do sangue que fizeram derramar" }\end{array}$} & "Nada mais vos posso dar a não ser meu sangue" \\
\hline 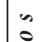 & \multicolumn{3}{|c|}{ Cristianismo $->$ palavras de Jesus Mateus 28: 20} & "Escolho este meio de estar sempre convosco" \\
\hline$\stackrel{2}{0}$ & \multicolumn{3}{|c|}{$\begin{array}{l}\text { Cristianismo -> linguagem arcaica } \\
\text { Paganismo -> esoterismo - conceito de chama imortal }\end{array}$} & $\begin{array}{c}\text { "Quando vos vilipendiarem, sentireis no meu pensamento } \\
\text { a força para a reação. [...] Cada gota de meu sangue será } \\
\text { uma chama imortal na vossa consciência [...]” }\end{array}$ \\
\hline & \multicolumn{3}{|c|}{$\begin{array}{l}\text { Cristianismo -> ideal do perdão, alusão à oração de S. Francisco } \\
\text { de Assis }\end{array}$} & "Ao ódio respondo com perdão" \\
\hline & \multicolumn{3}{|c|}{$\begin{array}{l}\text { Cristianismo -> palavras de Paulo } 1 \text { Coríntios 9: } 19 \\
\text { Trabalhismo -> conceito de liberdade social }\end{array}$} & "Era escravo e hoje me liberto" \\
\hline & \multicolumn{3}{|c|}{$\begin{array}{l}\text { Cristianismo -> Marcos 10: } 45 \text { (ex.: Jesus) } \\
\text { Judaísmo (ex.: Isaque) } \\
\text { Helenismo (ex.: Sócrates) }\end{array}$} & "Meu sangue terá o preço do seu resgate" \\
\hline & \multicolumn{3}{|c|}{$\begin{array}{l}\text { Trabalhismo -> ideal da nacionalização e dos direitos trabalhis- } \\
\text { tas }\end{array}$} & $\begin{array}{l}\text { "Lutei contra a espoliação do Brasil. Lutei contra a } \\
\text { espoliação do povo" }\end{array}$ \\
\hline & \multicolumn{3}{|c|}{ Cristianismo -> João 10: 15} & "Eu vos dei a minha vida" \\
\hline & \multicolumn{3}{|c|}{ Cristianismo -> João 10: 17} & "Agora ofereço a minha morte" \\
\hline & \multicolumn{3}{|c|}{$\begin{array}{l}\text { Jornalismo -> editoriais 0 Imparcial -> serenidade de profeta } \\
\text { Maquiavelismo -> conceito de homem providencial } \\
\text { Messianismo -> líder mártir } \\
\text { Positivismo -> castilhismo -> ideal de líder político e moral } \\
\text { que demanda devoção religiosa }\end{array}$} & $\begin{array}{l}\text { "Serenamente dou o primeiro passo no caminho da } \\
\text { eternidade e saio da vida para entrar na história" }\end{array}$ \\
\hline
\end{tabular}

Quadro 2: relações de evocação entre a carta-testamento e outras tradições discursivas 
Referências

ASSMANN, Jan. Das kulturelle Gedächtnis. Schrift, Erinnerung und politische Identität in frühen Hochkulturen. München: Beck, 1992.

BERKHOF, Louis. Teologia Sistemática. [trad. Odayr Olivetti] Campinas: Luz Para o Caminho, 1990.

CALVINO, João. As Institutas. [trad. Waldir Carvalho]. São Paulo: Cultura Cristã, 2006, p. 202.

CANÇADO, Marcia. Manual de Semântica. Belo Horizonte: UFMG, 2008.

CHÂTELET, François. Uma história da razão: entrevistas com Émile Noël. Tradução de Lucy Magalhães. Rio: Zahar, 1994 [1925].

COSERIU, Eugenio. Determinación y entorno. Dos problemas de uma linguística del hablar. Romanistisches Jahrbuch 7, 1955-1956.

COSERIU, Eugenio. Textlinguistik: Eine Einführung. Hrsg. und bearb. von Jörn Albrecht. Tübingen: Francke, 1994.

D’ARAUJO, Maria Celina (org.). Getúlio Vargas. Brasília : Câmara dos Deputados, Edições Câmara, 2011.

FARES, Seme Taleb. Antiamericanismo e politica externa: o caso do Brasil sob o paradigma desenvolvimentista.. In: $3^{\circ}$ ENCONTRO NACIONAL ABRI 2011, 3., 2011, São Paulo: Proceedings online. Associação Brasileira de Relações Internacionais Instituto de Relações Internacionais - USP, Available from: <http://www.proceedings.scielo.br/scielo.php?script=sci_arttext\&pid=MSC0000000122011000300045\&lng=en\&nrm=abn $>$. Acess on: 06 Jan. 2016.

FOSENCA, Pedro Cezar Dutra. As fontes do pensamento de Vargas e seu desdobramento na sociedade brasileira. In: Maria Thereza Rosa Ribeiro (org.). Intérpretes do Brasil; leituras críticas do pensamento social brasileiro. Porto Alegre: Mercado Aberto, 2001. p.103-124. GRIMAL, Pierre. Dicionário da mitologia grega e romana. Rio: Bertrand, 1993 [1951]. HENGEL, Martin. The atonement: A Study of the Origins of the Doctrine in the New Testament. Londres: SCM Press, 1981, 1-32.

JAKOBSON, Roman. "Lingüística e poética”. In: Roman Jakobson. Lingüística e comunicação (trad. Izidoro Blikstein e José Paulo Paes). 20ª ed., São Paulo: Cultrix, 118-162, 1995 [1960].

KABATEK, Johannes. ¿Es posible una lingüística histórica basada en un corpus representativo? In: Iberoromania 77 (2013), 8-28. DOI 10.1515.

KABATEK, Johannes. Die Bolognesische Renaissance und der Ausbau romanischer Sprachen.Tübingen: Niemeyer, 2005.

KABATEK, Johannes. Tradição discursiva e gênero, in: Tânia Lobo; Zenaide Carneiro; et al. (org.): Rosae. Linguística histórica, história das línguas e outras histórias, Salvador: EDUFBA, 2012, 579-588

KABATEK, Johannes. Tradições discursivas e mudança linguística. In: Tânia Lobo; Ilza Ribeiro; Zenaide Carneiro e Norma Almeida: Para a História do Português Brasileiro Volume VI: Novos Dados, Novas Análises. Tomo II. Salvador: EDUFBA, 2006, 505-527. KABATEK, Johannes; PUSCH, Claus. Spanische Sprachwissenschaft - Eine Einführung. Tübingen: Narr, 2009.

KOCH, Peter. Diskurstraditionen: zu ihrem sprachtheoretischen Status und ihrer Dynamik. In: Barbara Frank/Thomas Haye/Doris Tophinke (Hrsg.), Gattungen mittelalterlicher Schriftlichkeit, Tübingen: Narr 1997 (ScriptOralia, 99), 43-79. [tradução de Alessandra Castilho da Costa] 


\section{Conexão Letras}

LEDEEN, Michael A. Maquiavel e a liderança moderna. São Paulo: Cultrix, 1999.

LETHAM, Robert. A obra de Cristo. [trad. Valdeci da Silva Santos]. São Paulo: Cultura Cristã, 2007.

MAQUIAVEL, Nicolau. O príncipe. São Paulo: Nova Cultural, 1999.

MELLO, Renato de. Formação discursivo-ideológica e condições de produção na «Carta-Testamento» de Getúlio Vargas. Caligrama: Revista de Estudos Românicos, [S.1.], v. 7, p. 161-171, nov. 2011. ISSN 2238-3824. Disponível em: <http://www.periodicos. letras.ufmg.br/index.php/caligrama/article/view/362/317>. Acesso em: 05 Jan. 2016. doi:http://dx.doi.org/10.17851/2238-3824.7.0.161-171.

MENDONÇA, Carlos Vinícius Costa de; PEREIRA, Maria Rita De Cássia Sales;

RODRIGUES, Pablo De Andrade; LOSS, Bruno Zottele. Luz, escuridão e penumbra: o Governo Vargas e a Igreja Católica. In: Dimensões, vol. 26, 2011, p. 277-291.

OLIVEIRA, Danilo Ricardo. Argumentação, linguagem e história. Revista Línguas e Instrumentos Linguísticos, edição 31, p. 91-106, 2013.

RODRIGUES, Maria das Graças Soares; SILVA NETO, João Gomes da; PASSEGGI, Luis; MARQUESI, Sueli Cristina. A Carta-Testamento de Getúlio Vargas (1882-1954): genericidade e organização textual no discurso político. Filol. linguíst. port., n. 14(2), 2012, p. 285-307.

SILVA, Alexandre Marques. Discurso e identidade: breve caracterização linguístico-discursiva do populismo. Linha D’Água, Brasil: v. 25, n. 1, p. 109-130, jun. 2012. ISSN 2236-4242. Disponível em: <http://www.revistas.usp.br/linhadagua/article/ view/37370/40091>. Acesso em: 06 jan. 2016. doi:http://dx.doi.org/10.11606/issn.22364242.v25ilp109-130.

VIANNA, Alexander Martins. A Edificação do Corpo Místico de Vargas: Um Breve Estudo da Carta Testamento. Revista Espaço Acadêmico, Maringá: v. 47, n.47, p. 1-5, 2005. 